\title{
Job Demands and Job Resources in Human Service Managerial Work An External Assessment Through Work Content Analysis
}

\section{Linda Corin'}

$P h D$, researcher at the Institute of Stress Medicine, Region Västra Götaland and affiliated to the Department of Sociology and Work Science at University of Gothenburg, Sweden

\section{Lisa Björk}

$P h D$, researcher at the Institute of Stress Medicine, Region Västra Götaland and affiliated to the Department of Sociology and Work Science at University of Gothenburg, Sweden

\begin{abstract}
Managers' psychosocial working conditions are important for managerial sustainability in the public sector. The job demands-resources (ID-R) model is a widely applied and well-recognized framework for measuring psychosocial working conditions. However, there is still a need for methodological contributions including more objective as well as qualitative ways to assess these conditions. In this study, job demands and job resources as well as the balance between them was qualitatively and externally assessed for first-line human service managers using a work content analysis method. Conditions and actions were focused upon with an external perspective. Special attention was paid to concrete examples and consequences of work characteristics with predefined criteria and cut-off points to guide the assessments. The results reveal an imbalance for human service managers between high levels of job demands and the lack of job resources available to meet these demands. Work overload, conflicting and unclear goals and tasks, emotional demands, restricted control, and lack of supervisory and organizational support generally characterized the managerial assignment. The analysis provided concrete explanations of the current work strain in this group of employees, thereby giving both short-term and long-term possibilities for improvement of managerial work and sustainability.
\end{abstract}

\section{KEY WORDS}

External assessment / first-line managers / human service organizations / job demands / job resources / job demands-resources model / psychosocial working conditions / qualitative interviews / work content analysis

DOI

10.19154/njwls.v6i4.5610

\section{Introduction}

well-functioning management is a precondition for healthy and productive organizations. Since managers constitute a part of their subordinates' work environment, creating good working conditions for managers is thus not only a matter of

\footnotetext{
${ }^{1}$ Corresponding author: Linda Corin, Institute of Stress Medicine, Carl Skottbergs gata 22B, SE-413 19 Gothenburg, Sweden, E-mail: linda.corin@vgregion.se.
} 
improving the work situation for this group of influential people, but it is also an indirect way to care for the working conditions and occupational health of all employees, and ultimately a way to promote work engagement and organizational performance (e.g., Dellve et al., 2007; Hargreaves \& Fink, 2004; Nyberg, 2009).

Managerial work in human service organizations has changed during recent decades (Ball, 2003; Trydegård, 2000). Recent evidence from the human service sector points to a troublesome work situation, and to the problems of attracting and retaining skilled managers (Arman et al., 2009; Corin et al., 2016; Danielson et al., 2012; Höckertin, 2007; Skagert et al., 2012). First-line managers of human service organizations are particularly exposed and in disadvantageous work situations (e.g., Berntson et al., 2012; Björk, 2013). Recently, the theoretical and empirical insights from over 40 years of work stress research have developed into the job demandsresources (JD-R) model (Demerouti et al., 2001). To our knowledge, no studies have yet made comprehensive qualitative use of the JD-R model in first-level human services managerial work.

Here, we assess the job demands and job resources as well as the balance between them in first-level human service managerial work. The study applies the work content analysis method using the JD-R framework as a theoretical and analytical tool.

With qualitative interviews, following the work content analysis method, the job demands and job resources were addressed using an external perspective with the least possible consideration of emotional appraisals from the worker.

\section{Theoretical Framework}

\section{The Job Demands-Resources (JD-R) Model}

The JD-R model that was developed by Demerouti and colleagues in 2001 takes a balanced approach in explaining negative as well as positive aspects of occupational wellbeing, and the model has gained considerable empirical support (for an overview, see e.g., Schaufeli \& Taris, 2014). Job demands and job resources are assumed to cause two separate psychological processes. Job demands cost effort and consume resources, while job resources fulfill basic psychological needs (e.g., Bakker, 2011). Job demands are potential contributors to a health impairment process, whereas job resources facilitate the achievement of objectives and thus increase engagement and commitment through a motivational process (Bakker et al, 2010; Van den Broeck et al., 2013). More recent studies have also revealed interactions between these processes where job resources, for example, have been shown to buffer high job demands and thus protect from health problems (Bakker et al., 2005; Llorens et al., 2006).

The JD-R model is based on various instruments and measures that should be adapted and tailored to specific populations (Bakker \& Demerouti, 2007). Previous JD-R studies of public sector employees, some of them also including managers, have mainly emphasized the following job demands: workload, emotional demands, cognitive demands, role conflict, and role ambiguity (Dollard \& Bakker, 2010; Lizano \& Mor Barak, 2012; Van den Broeck et al., 2012). Job resources in this specific setting have largely included decision authority, skill utilization, organizational and supervisory 
support, social support from, for example, colleagues, performance feedback, and professional development (Bakker \& Xanthapolou, 2013; Dollard \& Bakker, 2010; Lizano \& Mor Barak, 2012; Van den Broeck et al., 2012).

The studies have mainly been performed through self-reported survey data. However, a common methodological problem is whether working conditions are correctly reported, over-reported, or underestimated (Theorell \& Hasselhorn, 2005). There is therefore still a need for methodological contributions including more objective as well as qualitative measures (e.g., Demerouti, 2014). In the following section, we present the ARIA method, which generates externally assessed qualitative data.

\section{External Assessment of Job Demands and Job Resources}

The ARIA method (see Waldenström, 2007 for an overview) draws on the German work psychology tradition (Greiner \& Leitner, 1989; Hacker, 1982), inspired by action theory and the particular concept of action regulation (Frese \& Zapf, 1994; Hacker, 2003). ARIA is a method suitable for exploring work content, work goals, job demands, and job resources. It was designed as a structured interview protocol (Waldenström et al., 1998) and has been validated against traditional models explaining stress as a consequence of demand-control imbalance (Waldenström et al., 2002), and used for classification of healthy and unhealthy jobs (Waldenström \& Härenstam, 2008b) and for assessing exposures in epidemiological studies of musculoskeletal and psychiatric disorders (Waldenström et al., 2002).

The working conditions are addressed from an external perspective, focusing on conditions and actions with the least possible consideration of emotional appraisals from the worker. The interview technique focuses on practice and action, rather than on opinions and emotion. In line with suggestions made by Semmer and colleagues (2003), the interviewer asks the respondents to be concrete and to provide examples and descriptions of consequences related to actions and work characteristics. These qualitative descriptions are then assessed against predefined criteria and/ or cut-off points to determine the presence and amount of a job demand or a job resource.

Although belonging to somewhat different research traditions, the JD-R model and the ARIA method rest upon similar foundations and unite in their ambition of capturing psychosocial working conditions and their consequences. The JD-R model explicitly expands and integrates classic balance models such as the Job demand-control-support (JDCS) model (Karasek \& Theorell, 1990) and the Effort-reward imbalance (ERI) model (Siegrist, 1996). The ARIA method similarly not only draws on the JDSC tradition but also on German work psychology adding dimensions such as work content and work goals. In line with their inheritance, both the JD-R model and the ARIA method thus take a balanced approach directing interest to a broad array of demands as well as resources at work. Thus, the ARIA method covers dimensions that in many respects resembles the recent developments in the field of stress theory and the JD-R model (Demerouti et al., 2001).

The following section provides an updated description of the dimensions studied in ARIA, as well as some developments of the method. 


\section{Methods}

\section{Sample and Procedure}

ARIA interviews were performed with six municipal school managers (three from compulsory school and three from preschool) and six elderly care managers (three from elderly care homes and three home care managers) within a municipality in western Sweden. The managers were all women of varying ages and managerial experience. Organizational and policy documents as well as calendars were also used for data analysis. The interviews lasted for approximately 2 hours and were conducted in 2013 at the managers' offices. The study was approved by the regional ethical committee in accordance with ethical standards (Dnr T839-13).

\section{ARIA's Dimensions}

The interviews covered the original ARIA dimensions (e.g., Waldenström et al., 1998, 2002). In addition, ore context-specific questions as well as questions about tasks that the managers experienced as illegitimate, that is, unnecessary or unreasonable (Semmer et al., 2007), were added to the original protocol.

\section{Contextual Information}

Initially, information on the respondent's position in the organizational hierarchy, the function of the closest supervisor, and the formal work assignment was collected. Information on the number of subordinates and units and the physical location of the manager in relation to the employees were added to the original protocol. The respondents were also asked about deteriorated work characteristics and job expansion defined as work tasks becoming more mentally demanding, more tasks being added, and/or new tasks replacing old ones (Waldenström \& Härenstam, 2008b).

\section{Work Tasks}

The work assignment and the particular tasks that comprise it were scrutinized. Work activities with a common goal were merged into one work task, and the relative proportion of actual work time spent on each task was defined. Diaries/calendars were used to assist the mapping process and possible unnecessary or unreasonable tasks were explored.

\section{Time Pressure and Time Binding}

The quantitative demands in the respondent's work were assessed as time pressure. In line with the predefined criteria and cut-off points (Waldenström, 2007; Waldenström et al., 2003), the work is considered to entail high time pressure if the work tasks cannot be unattended for more (or even less) than agreed pauses, not compensated with less hectic periods. If it varies during the day or week or only some work tasks entail high time pressure, the time pressure is assessed to be variable or moderate. If the work tasks 
can be completed in $80 \%$ of the work time, time pressure is defined as low. Time binding is an indicator of time constraints at work and assessed as the extent work tasks require conformance to schedule in a certain time or space (Waldenström et al., 2008).

\section{Work Hours}

The actual work hours per day, week, and month and the opportunities for overtime compensation were assessed.

\section{Work Goals}

The work goals deriving from several administrative and political levels as well as from the individual manager were studied. Formal and possible informal goals were disentangled. Information about how goal achievement is evaluated and concrete examples of consequences when goals are not fulfilled was also gathered.

\section{Social Interaction}

The amount of social interaction time between the manager and 1) supervisors, 2) colleagues, 3) employees, and 4) other actors (e.g., recipients and their relatives) were assessed reflecting emotional demands, as well as the opportunities for managers to work concentrated for uninterrupted periods of time.

\section{Influence}

Influence over the work situation was assessed through questions about the respondent's influence over what work tasks that were included in the work assignment, influence over how to conduct these tasks, as well as influence over where and when these tasks are performed. Similar to other scales (Karasek \& Theorell, 1990; Rau, 2004), the possibilities for exercising influence were categorized into four predefined levels: none, low, some, or high. The first level indicates that the work tasks and their execution, as well as time and place for work, are fixed. The second level indicates that some work tasks can be exchanged or done in a different order. The third level, on the other hand, includes possibilities to choose between work tasks and decide how, when, and where the tasks should be done for at least part of the day. The highest level of influence also includes a long-term, but not always short-term, influence over what tasks should be included in the work assignment (Waldenström \& Härenstam, 2008b; Waldenström et al., 2003).

\section{Cognitive Requirements and Possibilities}

Although active use of occupational knowledge, skills, and experiences shall constitute the largest proportion of the work assignment, all three levels should be present at work in order to reach a balance in cognitive requirements (Frese \& Zaph, 1994; Hacker, 1982). Three predefined levels are creativity/problem solving; active use of occupational knowledge, skills, and experiences; and routine work. The balance was assessed 
by asking the respondent for concrete examples of work tasks that involve regulation at each level and the proportion of time spent on these tasks.

\section{Resources at Work}

The next dimension covers the degree of goal and task clarity, and the access to premises and technical equipment, personnel resources and support functions, as well as social support from supervisors, employees, colleagues, and others. If deficiencies can be found in these job resources, they can obstacle action regulation and become hindrances at work in the sense that they hinder the achievement of job goals and require an increased expenditure of energy (Waldenström et al., 2002). To be considered a hindrance, at least one of two predefined criteria must be met-(1) an obvious loss of quality in the work result (more than accepted by the supervisor) and/or (2) a considerable delay ensuing overtime work, work without breaks, and/or work executed with an apparent risk of accident or illness (Waldenström \& Härenstam, 2008a).

\section{Analysis}

The interviews were transcribed and analyzed in accordance with the ARIA method. Particular attention was paid to the examples and descriptions of consequences related to each work characteristic, and the predefined criteria and cut-off points guided the analysis. The ARIA dimensions were also categorized as job demands or job resources.

\section{Results and Analysis}

The results are presented in two main sections: 1) job demands and 2) as the job resources managers have to balance these demands. Table I provides an overview of how ARIA's dimensions have been analyzed and categorized as job demands or job resources. The dimensions were matched with corresponding JD-R dimensions previously examined in empirical quantitative and qualitative JD-R studies conducted within a public sector setting and commonly used terms within this field.

The work situation was found to be highly similar between the managers working in the four different types of services except for some highlighted situations. Organizational context information revealed a span of control ranging from 25 to 55 subordinates, as well as generally one or two units that the manager is responsible for, while the geographical distribution of units/staff varied to a larger extent. In the following section, the results from the ARIA dimensions studied are arranged as job demands and job resources, respectively.

\section{Job Demands}

\section{Work Tasks}

The managers were responsible for three main work areas-personnel, financial, and operational matters-including the administrative procedures related to each area. 
Table I The main ARIA dimensions categorized as job demands and job resources in the context of human service managerial work matched with commonly studied corresponding dimensions in previous JD-R research

\begin{tabular}{|c|c|c|}
\hline & Dimensions in ARIA & $\begin{array}{l}\text { Examples of common corresponding } \\
\text { terms used in previous JD-R research }\end{array}$ \\
\hline \multirow{3}{*}{$\begin{array}{l}\text { Job } \\
\text { demands }\end{array}$} & $\begin{array}{l}\text { Work tasks } \\
\text { Time pressure } \\
\text { Time binding } \\
\text { Work hours } \\
\end{array}$ & Workload \\
\hline & $\begin{array}{l}\text { Work goals } \\
\text { Goal and task clarity } \\
\text { Unnecessary tasks } \\
\text { Unreasonable tasks }\end{array}$ & Role conflict and ambiguity \\
\hline & $\begin{array}{l}\text { Social interactions with: } \\
\text { - supervisors } \\
\text { - colleagues } \\
\text { - employees } \\
\text { - other actors (e.g., recipients and their relatives) }\end{array}$ & Emotional demands \\
\hline \multirow{4}{*}{$\begin{array}{l}\text { Job } \\
\text { resources }\end{array}$} & Influence (over what, how, where, and when) & Control/decision latitude \\
\hline & Cognitive requirements and possibilities & Skill discretion and learning opportunities \\
\hline & $\begin{array}{l}\text { Social support from } \\
\text { - supervisors } \\
\text { - colleagues } \\
\text { - employees } \\
\text { - other actors }\end{array}$ & Social support \\
\hline & $\begin{array}{l}\text { Premises and technical equipment } \\
\text { Personnel resources } \\
\text { Support functions }\end{array}$ & Organizational support \\
\hline
\end{tabular}

Unscheduled 'firefighting' generated a considerable amount of work, including managing acute staffing crises, intervention in staff conflicts, dealing with practical issues, and meeting urgent requests of clients and their relatives' to see the manager:

The daily matters take up a lot of time in everyday life as a manager, and you constantly have to reconsider everything. Much of the work time is taken up by meetings, and filling in information in various IT systems. As a first-line manager, you are constantly interrupted and operational work takes an incredible amount of time. The door is always open and the phone switched on in order to be accessible (Elderly care home manager).

Increased demands for reports, follow-ups, and monitoring on issues related to, for example, staff, finances, and service production from different stakeholders such as politicians, authorities, and support functions had resulted in a greater responsibility and a broader scope of work tasks, that is, job expansion. The use of standardized tools for management control had augmented. Thus, the workday was often fragmented, with a heavy and enhanced focus on administration and documentation, as opposed to 
long-term service development and leadership. The main work areas and related work activities and tasks are presented in detail in Table II.

\section{Time Pressure and Time Binding}

Time pressure was assessed as high with a constant demand for speed and intensity. Taking a break usually led to work piling up, and the manager had to work faster or

Table II The Human service managers' work assignment including main work areas and examples of included activities and tasks

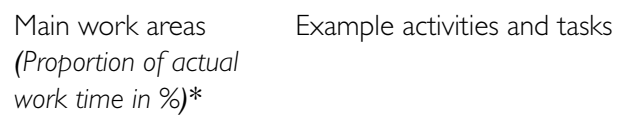

Personnel

(between 35\% and 40\%

in school services and between $30 \%$ and $35 \%$ in elderly care services)

I. Management of daily tasks/supervision through meetings and contact with staff, individually and in group, spontaneous and scheduled:

- Workplace meetings (APT)

- Work-team meetings

- Spontaneous or planned meetings/questions from individual staff members

- Work forums and conferences with different themes

- Management by walking around

- Management of acute staffing crises

2. Personnel planning, implementation, and follow-up:

- Individual appraisal talks, separate for development and salary

- Recruitment - e.g., writing demand profiles and ads, selecting candidates, conducting interviews, making the final selection, giving feedback to applicants

- Trainee and student management— e.g., making introductions, assigning mentors, evaluating

3. Work environment - management of health and safety issues

- Safety inspections and action plans, physical and psychosocial

- Rehabilitation and sick leave, dialogue, action plans, and follow-up

- Conflict management concerning relations between staff and/or staff and clients

- Disciplinary matters, unauthorized absences, late arrivals, theft, etc. (elderly care managers only)

Finance and administration (generally around 25\% of total work time, but with large variations of between $10 \%$ and $30 \%$ within elderly care services)
I. Budgeting, forecasts, and budget follow-up

2. Budget administration:

- Purchase and invoice certification

- Purchasing and leases

3. Personnel administration:

- Scheduling and work-time control

- Documentation and attest staff absences

- Documentation and follow-up of incidents, work injuries, and sick leave

- Rehabilitation - report and follow-up

- Grant leave and vacations

- Grant salaries, salary revision

4. Operations administration:

- Technical issues; setting up telephone connections, passwords, etc.

- Monitoring - e.g., children and elderly queues 


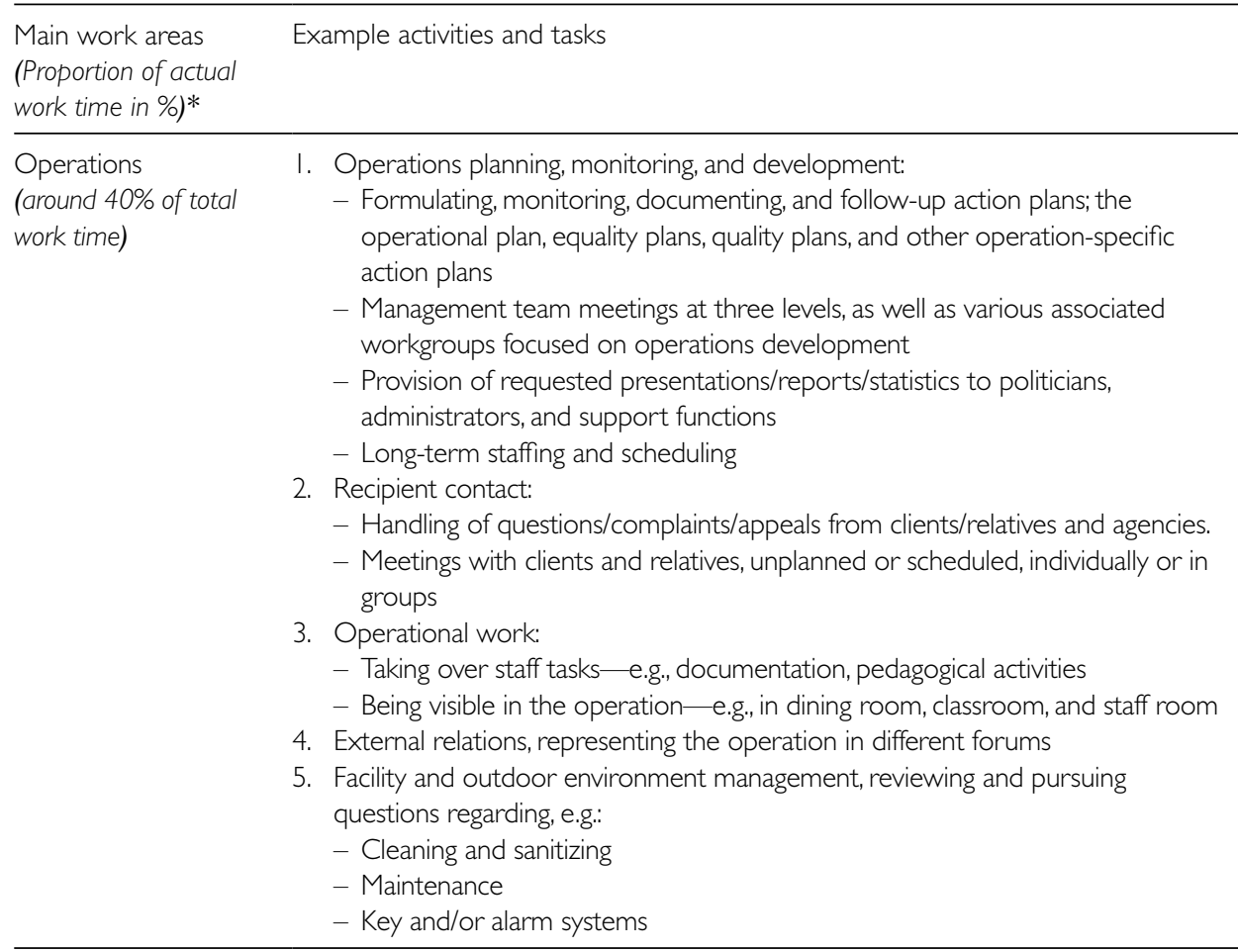

Note. *The actual work time varied heavily between individual managers and settings. In the care, setting managers on average worked $43 \mathrm{~h} /$ week (range 40-45 h/week), while the managers in the school setting on average worked $49 \mathrm{~h} /$ week (range $4 \mathrm{l}-65 \mathrm{~h} /$ week).

overtime. Time for trying and evaluating new work practices was lacking as well as time for reflection and informed and thoughtful decisions. Time for development and reflection together with the employees was even more limited. The managerial assignment rarely offered time for recovery at work. The time binding was assessed as moderate to high, since deadlines, scheduled meetings, and fixed work procedures regulated the managerial assignment to a large extent:

Budgetary work, tasks related to the operational plan, safety inspections, and appraisals: all of these are fixed procedures. In addition, queries from within—senior management, politicians, and support functions-and from without—clients and the media-should be responded to with short notice. At least half of the work time is moreover devoted to scheduled meetings (Compulsory school manager).

\section{Work Hours}

The managers often worked overtime. Extensive overtime was especially prevalent within the education services, where work weeks approaching 50 hours were common 
(see Table II). Some of the managers used the relative tranquillity of early mornings and late afternoons at the workplace to deal with tasks that required concentration. Working on the way to and from work and teleworking on evenings and weekends were common practices. Most of the managers had difficulties compensating for this overtime:

I try not to work too much, but it is hard. There are too many 'must-do's' that it is difficult to compensate for overtime. Compensating for overtime leads to too much to catch up on, and I do not want to let others down. Someone may take over the running operation, but everything else is left behind (Elderly care home manager).

\section{Work Goals}

The general objectives of municipal services are stipulated in the Local Government Act and in the specific act of municipal jurisdictions, in this case the Education Act and the Social Services Act. Governmental agencies such as the National Board on Health and Welfare and the Swedish National Agency for Education provide additional directives, for example, by providing evidence-based work procedures or rules of documentation. At the local level, politicians and senior management particularly emphasize that managers must keep services within the budgetary frame. In addition to this financial objective, several local service goals can differ between the organizations. Examples of measurable targets are to maintain a desirable number of children per teacher, or to reduce deviations and establish individual service plans within the care services. More elusive objectives could be to improve continuity in the client/provider relationship in elder care or to enhance staff participation in work environment issues. Operational plans could contain general techniques for local government control, such as codes of conduct, and standard procedures for how to manage discrimination, gender equality, and environmental issues within the services. In addition, various inter- and intra-sectorial bodies of cooperation, for example, assemblies of district managers of a specific service, produce guidelines for lower-level managers and staff. In addition, signals from employee- and client surveys; notifications from audit agencies; the media's writings; and most importantly, the unpredictable and multifaceted needs that arise in daily operations called for the manager to act. All these aspects had to be monitored within the overarching goal of a balanced budget:

The management and politicians focus on a balanced budget. Previously, I had a balanced budget and the senior managers and politicians were happy, but my staff was overloaded with work and the recipients complained. Nowadays, my staff is more satisfied as well as the recipients, while the balance in the budget is not as good. It doesn't add up (Home care manager).

\section{Goal and Task Clarity}

Hence, the work assignment was driven through goals from many different levels and directions that often collided in practice, especially within the school setting:

Rules regarding the state mission goes directly to the preschool manager and thus past the two management levels above. The result is that senior management often sees past the 
state mission and poses demands only in accordance with the local government commission that is more important to them. This means that the requirement according to the municipal commission basically fills the first-line managers' assignment, and that the state mission should be fulfilled on top of that. I constantly have to defend and fight for the Education Act and pedagogical leadership (Preschool manager).

Furthermore, formal documents or contracts specifying the work content of the managerial assignment were uncommon. While the tasks that stem from national and local politicians are relatively explicit, and often associated with specific targets and techniques to control goal completion, the tasks that arise from the operational reality were often implicit and informal.

\section{Unnecessary or Unreasonable Work Tasks}

The boundaries of the managerial assignment were unclear, and several activities were experienced as peripheral to the core assignment. When these tasks were regarded as consequences of organizational deficits, such as a lack of resources or unwise work organization, they can be understood as unnecessary or unreasonable in the sense that they violate the expectations of the managerial role:

Writing reports and providing statistics demanded by politicians are often delegated by the area manager to the principal. These types of requests become more and more common, and the requests often swell, since it is initially unclear what they are after (Compulsory school manager).

The most common examples of unnecessary work tasks are reports and follow-ups (e.g., indicators, action plans, and deviations) and the transmission of data already available elsewhere (dual reporting). The most common unreasonable work tasks reported are complicated personnel matters (e.g., rehabilitation cases, staff conflicts) and management of substitutes and attendance control. These tasks also include IT management (e.g., computer hassles, misplaced passwords, phone coverage) and purchasing. A large part of these unreasonable tasks are also made up of facility and outdoor environment management, including changing light bulbs, order ploughing and snow removal, allocating activities on bulletin boards, handling plumbing problems, monitoring indoor temperature, ordering office supplies, replacing printer toners, obtaining energy performance certificates, purchasing security systems, handling construction issues (roof renovations, etc.), taking care of rental contracts, managing keys, inspecting apartment as well as cleaning and janitorial tasks.

In sum, and according to the criteria of ARIA method, the conflicts and uncertainties regarding the goals and tasks included in the managerial role qualify as a hindrance in the fulfilment of the managerial assignment primarily by forcing the managers to comprise with work quality and working overtime.

\section{Social Interactions}

The social interactions necessary in the managerial work resulting in emotional demands typically stemmed from the service recipients' and their relatives (e.g., parents 
of schoolchildren and relatives of the elderly) or from other interested parties as well as their own employees. The managers had both formal and informal contacts with these recipients and their relatives. It could be scheduled meetings, as well as daily contacts by phone or email. The managers answered questions, took care of worries, and managed complaints. It had become more common for parents and other relatives to pursue matters with the media or with the audit authorities, such as the School inspectorate or the Health and Social Care Inspectorate, which caused much additional work for some of the managers:

The job has become more of a carousel. We are constantly watched by the media, and they only write when it is negative. The relatives focus on that and pose additional demands. I have to spend a lot of my time explaining how a politically controlled organization works. Most recipients, however, are satisfied, but the staff finds it difficult to tackle the relatives. There is no time to educate staff regarding these kinds of issues, and they are left feeling inadequate and worried. I do not know how to solve it (Elderly care home manager).

Although most of the managers occasionally dealt with some type of emotionally demanding employees, employee problems including conflicts, distrust, and complicated cases of rehabilitation were common in the elderly care settings. The elderly care managers sometimes had to take disciplinary actions when employees did not show up for work, or showed up too late.

\section{Job Resources}

\section{Influence}

The managers exert low to some influence or decision authority in their work in general. The content of the managerial assignment is largely determined by legislation and heavily influenced by demands from the large number of stakeholders and by unscheduled 'firefighting' as a result of issues arising from these stakeholders and the service operation. In order to be available for their employees, often working with overlapping schedules, the managers rarely closed their doors. This led to constant disruption, especially if the manager's office was situated close to the operational activities. In addition, the possibility of task delegation was limited owing to a heavy workload among the employees, and sometimes even more so in the care services because of a lack of adequate competence among the staff. The managers' influence over their work content (the what) was thus limited:

\footnotetext{
A large part of what first-line managers do would make sense to delegate to someone else- but there's no one to delegate to, at least not among the care staff. The managers must instead, as far as possible, try to offload the staff and facilitate their work (Home care manager).
}

However, managers did decide, to a certain extent, which meetings to attend and which workgroups to participate in. Managers also had an influence over the general and more long-term profile of their unit (e.g., organization of staff conferences and competence 
development). However, the many standardized tools for management control determined the work processes to a large extent. For example, IT-systems and standardized local procedures were found to highly regulate what the managers do and also how, where, and when they do it and to a greater extent than previously:

It is more difficult to influence what should be done in the short term than in the long term. The days consist of a lot of firefighting; employees can break down, parents call, schedules hassle, etc. At the end of the day, I have rarely done what I set out to do; the to-do list has increased rather than decreased (Preschool manager).

\section{Cognitive Requirements and Possibilities}

The results display that the managers made active use of their occupational knowledge, skills, and experience in their work. The work also included challenging tasks that could lead to skill development. For example, managers had to keep themselves updated on changes to rules and regulations. However, opportunities for problem solving and learning were often hampered by limited resources and time constraints. For example, managers did not always regard the extensive use of IT-systems, which could include handling more than 20 specific systems, to be an interesting, new, or helpful way to control the different work processes. They did not have time to learn and evaluate the software properly, and the many and sometimes clashing systems became a burden instead of tools for service improvement:

The systems should be simplified. They are complex and it takes too much time to learn. There are many specialists who come up with clever solutions related to their area of expertise, but these systems should work in real life too, side by side with amounts of other ‘smart systems' (Home care manager).

Routine work, that is, with no need for use of focused and conscious mental processes, was highly limited. Taken together, there was an imbalance between these three levels of cognitive requirements and possibilities in the managers' work.

\section{Social Support from Supervisors}

Supervisory support consisted of senior management acting as gatekeepers, taking on the responsibility for insufficiencies in the operation, and giving advice on operational issues. However, first-line managers were often left to set their own priorities and criteria for goal achievement and alone in dealing with the goal and role conflicts inherent in the complex managerial assignment. Given the elusiveness of intangible activities and processes in welfare services, the managers needed regular feedback, but this was often missing:

What is expected of me as a manager? When is it good enough? Is it enough that I report into [mentions a specific IT- system for operation control] that I have taken action, or should I specify what actions, when, and how? When do I know that I have achieved a 
high educational quality in the operation? When parents are satisfied according to a survey, or when they do not call me to complain? When my employees think I am a present manager, or when I have time to report into the IT-systems? And when there are more phone calls to me than to other principals, is it because my schools are of worse quality, or is it because I have schools with high client participation (Preschool manager).

The lack of supervisory support took its toll at the individual level in terms of a boundary-less assignment, often including substantial overtime work and risk of illness thus meeting the criteria of a bindrance to achievement of results:

I would like to get more guidance when dilemmas appear concerning children and parents. There are no opportunities for handling questions, problems, and dilemmas spontaneously, when the need arises. In combination with an unclear managerial assignment, I get disoriented and do everything myself, which leads to an unsustainable workload. Everyone handles this their own way; it is up to the individual (Preschool manager).

Furthermore, the managers often reported that a heavy workload at higher management levels prevented them from asking for help:

If I ask for help, I can expect support. But there are so many questions that arise from below; no one stops this flow. The district manager is so overloaded herself that there is no time to listen to the questions that arise in the operation (Compulsory school manager).

Another dimension that emerged during the interviews related to a perceived lack of trust in first-line managers by politicians, administrative staff, and senior management, indicating a disconnection between the operational needs and the management systems set up to control the operational work. This distance between the operational first-line managers and senior management, often enhanced by a physical distance, hampered the flow of communication and mutual understanding between the organizational levels:

What do they really think that principals are up to at work, when they constantly need to measure, evaluate, and micromanage our operations (Compulsory school manager).

\section{Social Support from Colleagues}

The managers received support from their colleagues mainly via scheduled management team meetings. These meetings were forums for joint reflection and operational planning in which the managers to some extent got help to cope with dilemmas and solve problems. However, the operation, and especially the economic aspects of it, was often the focus, not the managers' emotional or psychosocial needs in dealing with a demanding job. If provided, emotional support was mainly found during more informal meetings with colleagues:

I have good and experienced managerial colleagues whom I can bounce questions of and contact when I do not really know how to act. It can regard which issues to engage in and when it is better to just wait and see (Home care manager). 
For most of the managers, time was often so scarce that it precluded potential support from colleagues in the same situation that can be regarded as a disturbance or a source of irritation in the managerial assignment:

Social support requires space and time that do not exist today; managers do not have time to help each other or to be helped sufficiently (Preschool manager).

\section{Social Support from Employees}

In the school setting, the managers tended to have subordinates who showed good understanding of the managers' work situation, and took a lot of own responsibility to solve emerging problems. In the care setting, managers needed to be more available and provide more guidance for their employees in addition to be more controlling, for example, double-check that the employee had done the required documentation properly and the managers tended to take on many tasks that the employees were supposed to handle themselves due to lack of skill and commitment. There was, however, no time and no financial resources for competence development. Lack of skill and commitment among staff was assessed as a hindrance to goal achievement within the care services:

It would have been easier if the staff would be as independent as you could expect. In practice, a lot of my time is spent checking if my staff has done what they have committed to. It is often the case that they try to delegate the task further to someone else who does not perceive that they are necessarily responsible for the task either (Home care manager).

\section{Premises and Technical Equipment}

Many schools and elderly care premises were old and worn. School premises were often inappropriate for modern pedagogy, without small rooms for teamwork. Meeting rooms in the care services were small, if they existed at all. It could thus be impossible to gather staff. Technical equipment for presentations was sometimes missing. Other examples of technical deficiencies, which particularly affect managers in care services, were key saves and IT-systems that did not work correctly and lack of computers for required documentation:

\footnotetext{
Despite brand new facilities, there are many problems attached to the material resources. There are large problems with the cell-phone coverage. There are also key saves that do not work properly, which has caused conflicts with the IT- department. A computer that logs when an alarm from one of the elderly has occurred is missing, which means that it is not possible to track what has happened and what actions have been taken, which means that word stands against word when relatives complain. These problems lead to a lot of conflicts (Elderly care home manager).
}

The premises and technical equipment and attached consequences were assessed as a hindrance to goal achievement in the care settings and as a disturbance or source of irritation in the school setting. 


\section{Personnel Resources}

In elderly care services, short- and long-term sick leaves and staff shortages impeded service continuity, one of the main objectives in the social care. The ordinary team had to cover for absent colleagues, since most work tasks could not be postponed. In the preschool services, it was difficult to recruit experienced preschool teachers. Competing with higher wage levels was not an option owing to budgetary constraints. Although for different reasons, the personnel resources were thus lacking in both the care and school settings, constituting a hindrance to goal achievement in the managerial assignment.

\section{Support Functions}

Specialists in HR, IT, and accounting assisted the managers in their daily work regarding issues such as recruitment, legal matters, purchases, and financial planning. However, even though these functions primarily were supposed to support the services, they often had a mandate to develop their field of expertise vis-à-vis the services. The managers provided several examples of how these functions had become more demanding and less supportive than before:

If you as a first-line manager do everything that the HR department asks you to, there is no room for operational issues. They have good ideas but they are not adapted to the prerequisites in the operation (Preschool manager).

Yet, the managers' need for operative assistance had increased. Issues related to human resource management (HRM) such as employee rehabilitation could become complicated and time-consuming, and many of the managers sought more expertise and handson assistance in order to be able to fulfil their work assignment and even follow the law thus constituting a hindrance to goal achievement:

Sometimes I can have as many as 10 cases of rehabilitation running simultaneously, and those can concern serious matters such as abuse at home, theft, and the like. HR is no real support on these issues. Specialists who report to me as a manager should really handle these cases. I can be entirely occupied with single cases at the expense of everything else that needs to be done (Home care manager).

Additionally, facility management and purchasing were areas where more professional assistance was needed. Most of the managers had access to a part-time administrator or assistant, while others had part- or full-time coordinators or team leaders who handled daily issues such as staffing, scheduling, and morning meetings. However, the quality of these services varied heavily, which had considerable consequences for the offloading effect in the manager's work.

\section{Discussion}

In contrast to most other contemporary studies on managerial work in the public sector, this study externally assessed human service managers' psychosocial working conditions. 
The results of the assessment showed that high job demands in terms of work overload, conflicting and unclear goals and tasks, emotional demands in combination with a lack of resources including restricted control, lack of supervisory and organizational support generally characterized the managerial assignment. Hence, the results revealed an imbalance for human service managers between high levels of job demands and a lack of job resources available to meet these demands.

\section{Workload became Work Overload}

The human service managers were responsible for a broad scope of varying work tasks including a large amount of unscheduled 'firefighting' activities. Changes increasing demands for reports, follow-ups, and monitoring on a broad scope of issues in addition to a greater use of standardized tools for management control have caused a job expansion of the managerial role. The managers spent less time on leadership and service development, and more time on administrative tasks, with a heavy focus on documentation. A similar trend has been spotted in several public sector domains in Sweden, as well as in other countries (e.g., Hagerman, 2014; Levin \& Fullan, 2008; Rapp, 2010; Wolmesjö, 2008). New public management (NPM) ideals may be one reason for the increase of administrative tasks linked to accountability and the continuously scrutinizing of processes, improvements, performance, results, costs, and customer satisfaction (Abma \& Noordegraaf, 2003; Pollitt \& Bouckaert, 2000) at the same time as the direct administrative support often has decreased (Arman et al., 2009; Höckertin, 2007). Although a high workload can constitute a positive challenge in a job (Crawford et al., 2010), work overload has been associated with ill-health (e.g., Schaufeli \& Bakker, 2004). This makes the managers of this study a high-risk group for health impairment.

In addition, the managerial assignment was largely time-bound with complex, fragmented, and event-driven work rarely offering moments for recovery and reflection. At the end of the day, the managers had rarely accomplished the tasks they set out to do in the morning (cf. Day et al., 2000). Delegation of tasks was often hindered by a heavy workload or lack of knowledge among the staff leading to high time pressure. This situation is highly troublesome, since it hinders switching-off of work-related thoughts and thus recovery from work (Syrek et al., 2014). Especially the education service managers worked extensive overtime. Similar to results found among elderly care managers in Sweden by Antonsson (2013), the managers of this study had a deliberate strategy to work before or after regular office hours, in order to concentrate on one task at the time.

\section{Borderless Work}

Goal conflicts as well as conflicts and ambiguity concerning the managerial role were highly present in the managers' work, leading to a work assignment with elusive borders. The results support previous findings among managers both in Swedish elderly care (Wolmesjö, 2008) and school services (Brüde Sundin, 2007). The vast number of goals and tasks frequently collided in practice. For instance, reaching a balanced budget overshadowed and often clashed with other objectives, laws, regulations, and interests (cf. Hagerman, 2014). Conflicting organizational goals can be a significant source of role 
ambiguity in public sector organizations (Rainey \& Chun, 2005). To take all stakeholders into account as well as understanding and handling the boundaries of the managerial assignment was challenging and frequently impossible task for the managers. These conflicts and uncertainties qualify as a hindrance in the fulfilment of the managerial assignment primarily by forcing the managers to comprise with work quality and working overtime.. Role conflict and lack of role clarity have previously been reported as a problem for managers in Swedish schools and elderly care (Ekholm, 2012; Swedish Schools Inspectorate, 2012).

It was also unclear when the managers had achieved adequate results. Quantitative indicators do not grasp and evaluate the qualitative aspects of human service work. Within the public sector, qualitative goals are often vaguely phrased and the performance criteria are unclear (Moynihan \& Pandey, 2007). There were also several work activities that the managers viewed as peripheral to the core assignment. Peripheral tasks have previously shown to be associated with stress (Semmer et al., 2007).

\section{Emotionally Demanding Work}

Demands and negative feedback from recipients and their relatives, as well as negative media attention, were common and have previously been referred to as emotional demands (Waldenström et al., 2002; Zapf, 2002). Problems related to employee groups or individuals, characterized by conflicts, distrust, disciplinary actions, and complicated rehabilitation cases further added to the emotional demands, particularly in the elderly care setting (cf. Berntson et al., 2012).

\section{Restricted Control}

Extensive research has shown the importance of job resources for motivational outcomes (Bakker et al., 2014) and to tackle or buffer high job demands, thus reducing health problems (Bakker et al., 2007). Control, consisting of decision authority and skill discretion, has been argued to be one of the most important resources in tackling a demanding work situation (Karasek \& Theorell, 1990). However, our results show that the decision authority to a large extent is restricted by legislation, organizational procedures, standardized tools for management control, and firefighting activities. The managers' skill discretion was assessed as high, since the managers made extensive use of their previous experience and knowledge. However, the opportunities for learning and skill development were heavily constrained by limited resources and by a high workload, both among the managers themselves and among their employees. The main cognitive requirement on this higher mental level was also problem-solving related to hindrances in the organization (cf. Waldenström, 2007). The extensive use of previous knowledge and experience, in combination with limited development opportunities and almost no routine work enabling recovery, leads to a work assignment with imbalanced cognitive requirements (Frese \& Zaph, 1994; Waldenström, 2007), thus hampering the health-promoting effect of using different cognitive levels (Waldenström et al., 2002). 


\section{Inadequate Social Support}

The emotional as well as the instrumental support were assessed as inadequate in most of the care managers' work. This should be considered as a hindrance to satisfactory job performance, as well as an indicator of an inappropriate work organization (Waldenström, 2008). Good social relationships are a highly important resource in order for managers to handle demands and avoid stress, particularly for those managers with less managerial experience and many subordinates (Dellve, 2013), which was also the case for several of the managers in the present study, thus making them a high-risk group.

The support from managerial colleagues was generally high, but the important emotional or instrumental needs to deal with a demanding job were often overshadowed by dealing with more acute operational problems.

In the educational services, the support from the employees was generally high, where the teachers facilitated the manager's work. In the care settings, on the other hand, the employees needed more guidance and monitoring, and the managers tended to take on many tasks that the employees were supposed to handle themselves. Berntson et al (2012) has similarly found that managers' relations to their employees typically differ between the care and school setting.

In both areas, the supervisory support was assessed as inadequate in terms of delimiting the managers' assignment, prioritizing among work goals and tasks, setting criteria for goal achievement, and solving emerging problems. Performance feedback and dialogue was often lacking especially with supervisors, resulting in divergent understandings of organizational preconditions and a lack of role clarity, also noted by Törnsén (2010) and Waldenström (2007). These uncertainties were assessed as a hindrance in the fulfilment of the managerial assignment causing both substantial overtime and early signs of illness. A perceived lack of trust in first-line managers by politicians, administrative staff, and senior management was also identified indicating a disconnection between the operational needs and the management systems set up to control the operational work.

\section{Decreased Organizational Support}

In contrast with other examples (e.g., Antonsson, 2013), most managers in this study had access to at least a part-time administrator and/or coordinator. They reduced the managers' workload, but the quality and qualifications of these staff members differed and often needed to be improved. The care managers provided several examples of how the professional support functions, such as HR and IT specialists, have become more demanding and less operative, while the managers' need for professional assistance has increased. Dellve and colleagues (2006) have shown that the lack of such organizational support resources may increase the risk of stress and illness among health care managers. Organizational support in terms of personnel resources was a problem for the managers, although in different ways. The care services were often short-staffed owing to sick leaves, while the school services struggled with recruiting and filling vacancies. Furthermore, worn-down facilities, a lack of appropriate meeting rooms, flawed technical equipment, and poor technical support were other examples of poor organizational support, also pointed out by the Swedish Work Environment Authority (2014). Taken 
together, the underprovided organizational support constitutes a hindrance for fulfilment of the managerial assignment.

\section{Methodological Considerations}

When we make use of the entire spectrum of the JD-R model, it becomes clear that the aspect of the two dimensions should be treated cautiously (Van den Broeck et al., 2013). Whether a job characteristic is conceptualized as a job demand or a job resource is a matter of empirical investigation and the conceptual difference between a job demand or job resources is dependent on, for example, the amount of energy spent and whether it is negatively or positively valued in the specific context (Schaufeli \& Taris, 2014). Thus, this study supports previous discussions on the JD-R model as highly embedded in context.

External assessments of the working conditions can be valuable in validating other qualitative as well as quantitative results, especially among managers that repeatedly have shown to underestimate unadvantagous work situations and ill-health (e.g., Skagert et al., 2012). Furthermore, in order to avoid over-reporting of unfavorable work characteristics among those with psychological distress, it is preferable to use methods that aim to distinguish the actual conditions from the individual's emotional response to them (Waldenström et al., 2008). Even so, the respondents' subjective appraisal of the work environment cannot be fully avoided. External assessments are less influenced by the subject's cognitive and emotional processing. Hence, there should be less measurement bias related to other psychological and behavioral conditions (Frese \& Zaph, 1988). With that said, the ARIA method lacks exact criteria for leaving information out because of emotional bias and therefore relies heavily on the skills of the assessors. Although such criteria would be a highly beneficial development in order to enhance reliability and accessibility of the method in the future, the assessors in this study were thoroughly trained in the ARIA method.

\section{Contribution}

This study makes important contributions to the research field of psychosocial working conditions, as well as to the practice of managerial work in the public sector. The ARIA method used covers a broad array of job demands and job resources usually found within the JD-R field and can thus be used to qualitatively operationalize and capture the central components of the JD-R model in depth. In addition to a comprehensive array of more widely studied job demands and job resources, the ARIA methods also includes an analysis of work content, which was identified as an important job demand and thus potential stressor (Sauter et al., 1990; Swedish Work Environment Authority, 2014). With its external assessment of job demands and job resources, and thus contextualized and more objective measures, the ARIA method provides an important methodological contribution developing the JD-R research field further. It has previously been argued that even though the JD-R model is a widely applied framework, there is a need for methodological contributions including more objective as well as qualitative ways to assess these conditions (Demerouti, 2014).

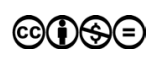


In this study, we have taken a wide-ranging approach by studying a multitude of job demands and job resources relevant for human service managers, thereby giving a comprehensive picture of their work assignment. In sum, the results reveal that the job demands are high, while the job resources that are supposed to balance these demands according to the JD-R framework are largely lacking, especially within the care settings. The detailed knowledge gained by the external assessment of working conditions also have the advantage over more traditional JD-R research to provide several ideas for improvements to managers' working conditions that may reduce significant individual as well as organizational costs.

As a sensible first step, the high job demands should be supplemented with relevant and reasonable job resources-not only because the absence of resources can lower job satisfaction, commitment, and engagement but also because these resources are known to reduce job demands and thus the health impairment process (e.g., Demerouti et al., 2001). However, it is not enough to only increase the resources, since they can only compensate for high demands to a certain point. From a preventive point of view, decreasing job demands is even preferred above increasing job resources (Schaufeli \& Bakker, 2004). Preferably and realistically, however, both aspects of the psychosocial working conditions should be approached, in order to tackle the imbalance.

Discussions about the role of managers and their work content, and what they need to devote their limited time to could preferably be initiated as a first step. Actions should, for example, be taken to organize work in order for first-line managers to receive the support they need to delimit the assignment and thus avoid work overload as well as role conflict and ambiguity. Furthermore, we argue that unless the human service organization in which the managers in the present study work can formulate when performance is good enough, the work assignment risks becoming boundless and unlimited, and work intensity increasing. Organizational support in terms of professional support functions, personnel resources, premises, and technical resources should be overseen and improved in order not to hinder the fulfilment of the managerial assignment. For instance, if the tasks of HR professionals and others are becoming more strategic and specialized, the question must be raised regarding who will assist operational managers with the wide range of operative and administrative personnel-related duties (Thilander, 2013). Investigating and developing models for cooperation between support units and operations managers, in order to find relevant and effective division of tasks, without compromising any of the occupational groups' professionalization efforts can be considered essential.

Consequently, the results support a demand for redesigning public sector managerial work, rather than the managers individual's behavior and mindset, in order to remove several of the hindrances present in their work and thus enhance performance and promote sustainable jobs (see, e.g., Frese \& Zaph, 1988; Rau, 2004).

The next step in practice would desirably be to take actions on the practical implications of this study. Future research should beneficially be directed toward how such ideas for improvements could best be put into practice but also to further utilize and develop the ARIA method as a useful way of operationalizing the JD-R model. Finding such relevant ways of investigating job demands and job resources in depth could be considered especially important, since the new provisions in the Organizational and Social Work Environment report from the Swedish Work Environment Authority (2015), which came into effect in March 2016, states that resources should be adapted to the demands at work. 


\section{References}

Abma, T. A., and Noordegraaf, M. (2003). Public managers amidst ambiguity: Towards a typology of evaluative practices in public management. Evaluation, 9(3): 285-306. doi: http://dx.doi.org/10.1177/13563890030093004.

Antonsson, H. (2013). Chefers arbete i äldreomsorgen-att hantera den svårhanterliga omvärlden: Relationen mellan arbete och organisering [Managers work in the elderly care-managing the unwieldy world: The relationship between work and organization]. (Doctoral dissertation, Linköping University, Sweden). Retrieved from: liu.diva-portal. org/smash/get/diva2:647832/FULLTEXT01.pdf.

Arman, R., Dellve, L., Wiktröm, E., and Törnström, L. (2009). What health care managers do: Applying Mintzberg's structured observation method. Journal of Nursing Management, 17(6): 718-729. doi: http://dx.doi.org/10.1111/j.1365-2834.2009.01016.x.

Bakker, A. B. (2011). An evidence-based model of work engagement. Current Directions in Psychological Science, 20(4): 265-269. doi: http://dx.doi.org/10.1177/0963721411414534.

Bakker, A. B., Demerouti, E., and Euwema, M. C. (2005). Job resources buffer the impact of job demands on burnout. Journal of Occupational Health Psychology, 10(2): 170-180. doi: http://dx.doi.org/10.1037/1076-8998.10.2.170.

Bakker, A. B., Demerouti, E., and Sanz-Vergel, A. I. (2014). Burnout and work engagement: The JD-R approach. Annual Review of Organizational Psychology and Organizational Behavior, 1(1): 389-411. doi: http://dx.doi.org/10.1177/0963721411414534.

Bakker, A. B., van Veldhoven, M., and Xanthopoulou, D. (2010). Beyond the demand-control model: Thriving on high job demands and resources. Journal of Personnel Psychology, 9(1): 3-16. doi: http://dx.doi.org/10.1027/1866-5888/a000006.

Bakker, A. B., and Xanthopoulou, D. (2013). Creativity and charisma among female leaders: The role of resources and work engagement. International Journal of Human Resource Management, 24(14): 2760-2779. doi: http://dx.doi.org/10.1080/09585192.2012.751438.

Ball, S. J. (2003). The teacher's soul and the terrors of performativity. Journal of Education Policy, 18(2): 215-228. doi: http://dx.doi.org/10.1080/0268093022000043065.

Berntson, E., Wallin, L., \& Härenstam, A. (2012). Typical situations for managers in the Swedish public sector: Cluster analysis of psychosocial working conditions using the job demands-resources model. International Public Management Journal, 15(1): 100-130. doi: http://dx.doi.org/10.1080/10967494.2012.684026.

Björk, L. (2013). Contextualizing managerial work in local government organizations, (Doctoral dissertation, University of Gothenburg, Sweden). Retrieved from: https:/gupea. ub.gu.se/handle/2077/34265.

Brüde Sundin, J. (2007). En riktig rektor: Om ledarskap, genus och skolkulturer [A real headmaster: About leadership, gender and school cultures], (Doctoral dissertation, Linköping University, Sweden). Retrieved from: www.diva-portal.org/smash/get/diva2:18015/ FULLTEXT01.pdf.

Corin, L., Berntson, E., \& Härenstam, A. (2016). Managers' Turnover in the Public SectorThe Role of Psychosocial Working Conditions. International Journal of Public Administration, 39(10): 790-802. doi: http://dx.doi.org/0.1080/01900692.2015.1035786.

Crawford, E. R., LePine, J. A., and Rich, B. L. (2010). Linking job demands and resources to employee engagement and burnout: A theoretical extension and meta-analytic test. Journal of Applied Psychology, 95(5): 834-848. doi: http://dx.doi.org/10.1037/a0019364.

Day, C., Harris, A., Hadfield, M., Tolley, H. and Beresford, J. (2000). Leading schools in times of change. Milton Keynes, England: Open University Press.

Dellve, L., Andreasson, J., and Jutengren, G. (2013). Hur kan stödresurser understödja hållbart ledarskap bland chefer $i$ vården? [How can support resources create sustainable leadership among managers in healthcare?], Socialmedicinsk tidskrift, 90(6): 866-877. 
Dellve, L., Skagert, K., and Vilhelmsson, R. (2007). Leadership in workplace health promotion projects: 1-and 2-year effects on long-term work attendance. European Journal of Public Health, 17(5): 471-476. doi: http://dx.doi.org/10.1093/eurpub/ckm004.

Dellve, L., Wikström, E., and Ahlborg, G. (2006). Hållbart ledarskap i sjukvården: utveckling av ledarskap och stödstrukturer ur individ-och organisationsperspektiv. [Sustainable Leadership in Health Care: Developing Leadership and Support Structures from an Individual- and Organizational Perspective]. Gothenburg, Sweden: University of Gothenburg.

Demerouti, E., Bakker, A. B., Nachreiner, F., and Schaufeli, W. B. (2001). The job demands-resources model of burnout. Journal of Applied Psychology, 86(3): 499-512. doi: http:// dx.doi.org/10.1037/0021-9010.86.3.499.

Demerouti, E. (2014, April). Job demands and job resources: Given and crafted. Keynote speech delivered at the 11th conference of the European Academy of Occupational Health Psychology, London, England.

Dollard, M. F., and Bakker, A. B. (2010). Psychosocial safety climate as a precursor to conducive work environments, psychological health problems, and employee engagement. Journal of Occupational and Organizational Psychology, 83(3): 579-599. doi: http:// dx.doi.org/10.1348/096317909X470690.

Ekholm,B.(2012), Middlemanagers in elderly care underdemands and expectations.Leadership in Health Services, 25(3): 203-215. doi: http://dx.doi.org/10.1108/17511871211247642.

Frese, M., and Zaph, D. (1988). Methodological issues in the study of work stress: Objective vs subjective measurements of work stress and the question of longitudinal studies. In C. L. Cooper and R. Payne (Eds.), Causes, coping and consequences of stress at work (pp. 115-140). Oxford, England: John Wiley and Sons.

Frese, M., and Zapf, D. (1994). Action as the core of work psychology: A German approach. Handbook of Industrial and Organizational Psychology, 4: 271-340.

Greiner, B., and Leitner, K. (1989). Assessment of job stress: The RHIA-Instrument. In K. Landau and W. Rohmert (Eds.), Recent developments in job analysis: Proceedings of the international Symposium on job analysis, University of Hohenheim (pp. 53-66). London, England: Taylor and Francis.

Hacker, W. (1982). Objective and subjective organization of work activities. In M. Cranach and R. Harre (Eds.). The analysis of action (pp. 73-91). Cambridge, England: Cambridge University Press.

Hacker, W. (2003). Action regulation theory: A practical tool for the design of modern work processes? European Journal of Work and Organizational Psychology, 12(2): 105-130. doi: http://dx.doi.org/10.1080/13594320344000075.

Hagerman, H., Engström, M., Häggström, E., Wadensten, B., and Skytt, B. (2014). Male firstline managers' experiences of the work situation in elderly care: An empowerment perspective. Journal of Nursing Management. doi: http://dx.doi.org/10.1111/jonm.12197.

Hargreaves, A., and Fink, D. (2004). The seven principles of sustainable leadership. Educational Leadership, 61(7): 8-13.

Höckertin, C. (2007). Organisational characteristics and psychosocial working conditions in different forms of ownership. (Doctoral dissertation, University of Umeå, Sweden). Retrieved from: www.diva-portal.org/smash/.../FULLTEXT01.pdf.

Karasek, R. A., and Theorell, T. (1990). Healthy work: Stress, productivity and the reconstruction of working life. New York, NY: Basic Books Harper.

Levin, B., and Fullan, M. (2008). Learning about system renewal. Educational Management Administration and Leadership, 36(2): 289-303. doi: http://dx.doi.org/10.1177/ 1741143207087778.

Lizano, E. L., and Mor Barak, M. E. (2012). Workplace demands and resources as antecedents of job burnout among public child welfare workers: A longitudinal study. 
Children and Youth Services Review, 34(9): 1769-1776. doi: http://dx.doi.org/10.1016/j. childyouth.2012.02.006.

Moos, L., and Johansson, O. (2000). Skoleledelse i Norden: En kortlaegning af skoleledernes arbejdsvilkår, rammebetingelser og Opgaver: En rapport til Nordisk Ministerråd [School leadership in the Nordic countries: A mapping of principals' working conditions, frame conditions, and tasks: A report to the Nordic Ministry Council]. Copenhagen, Denmark: Nordick Council of Ministers.

Moynihan, P., and Pandey, S. (2007). The ties that bind. Social networks, person-organization value fit, and turnover intention. Public Administration Research and Theory 18(2): 205-227. doi: http://dx.doi.org/10.1093/jopart/mum013.

Noordegraaf, M., and Stewart, R. (2000). Managerial behaviour research in private and public sectors: Distinctiveness, disputes and directions. Journal of Management Studies, 37(3): 427-443. doi: http://dx.doi.org/10.1111/1467-6486.00187.

Nyberg, A. (2009). The impact of managerial leadership on stress and health among employees. (Doctoral dissertation, Karolinska Institutet, Sweden). Retrieved from: diss.kib. ki.se/2009/978-91-7409-614.../thesis.pdf.

Pollitt, C., and Bouckaert, G. (2000). Public management reform: A comparative analysis. Oxford, England: Oxford University Press.

Rainey, H., and Chun, Y. (2005). Public and private management compared. In E. Ferlie, L. Lynn, and C. Pollitt (Eds.), The Oxford handbook of public management (pp. 72-102). Oxford, England: Oxford University Press.

Rapp, S. (2010). Head teacher as pedagogical leader: A comparative study of head teachers in Sweden and England. British Journal of Educational Studies, 58(3): 331-349. doi: http:// dx.doi.org/10.1080/00071001003752229.

Rau, R. (2004). Job strain or healthy work: A question of task design. Journal of Occupational Health Psychology, 9(4): 322-338. doi: http://dx.doi.org/10.1037/1076-8998.9.4.322.

Sauter, S. L., Murphy, L. R., and Hurrell, J. J. (1990). Prevention of work-related psychological disorders: A national strategy proposed by the National Institute for Occupational Safety and Health (NIOSH). American Psychologist, 45(10): 1146-1158. doi: http://dx. doi.org/10.1037/0003-066X.45.10.1146.

Schaufeli, W. B., and Bakker, A. B. (2004). Job demands, job resources, and their relationship with burnout and engagement: A multi-sample study. Journal of Organizational Behavior, 25(3): 293-315. doi: http://dx.doi.org/10.1002/job.248.

Schaufeli, W. B., and Taris, T. W. (2014). A critical review of the job demands-resources model: Implications for improving work and health. In G. Bauer and O. Hämmig (Eds.), Bridging occupational, organizational and public health (pp. 43-68). Dordrecht, The Netherlands: Springer.

Semmer, N. K., Grebner, S., and Elfering, A. (2003). Beyond self-report: Using observational, physiological, and situation-based measures in research on occupational stress. Research in Occupational Stress and Well-being, 3: 205-263.

Semmer, N. K., Jacobshagen, N., Meier, L. L., and Elfering, A. (2007). Occupational stress research: The "stress-as-offense-to-self" perspective. Occupational Health Psychology: European Perspectives on Research, Education and Practice, 2: 43-60.

Siegrist, J. (1996). Adverse health effects of high-effort/low-reward conditions. Journal of Occupational Health Psychology, 1(1): 27-41. doi: http://dx.doi.org/10.1037/10768998.1.1.27.

Skagert, K., Dellve, L., and Ahlborg, G., Jr. (2012). A prospective study of managers' turnover and health in a healthcare organization. Journal of Nursing Management, 20(7): 889- 899. doi: http://dx.doi.org/10.1111/j.1365-2834.2011.01347.x. 
Stansfeld, S., and Candy, B. (2006). Psychosocial work environment and mental healthA meta-analytic review. Scandinavian Journal of Work, Environment and Health, 443-462.

Swedish Schools Inspectorate. (2012). Rektors ledarskap med ansvar för den pedagogiska verksambeten [The headmasters responsibility for the pedagogic leadership], Report, 2012(1). Swedish School Inspectorate, Stockholm, Sweden.

Swedish Work Environment Authority. (2014). Inspections of female and male dominated municipal activities, home care services and technical administration. Stockholm, Sweden: Author. (Report 2014:3)

Swedish Work Environment Authority. (2015). Organizational and social work environment. Stockholm, Sweden: Author. (AFS 2015:4).

Syrek, C., Antoni, C., and Hoheluechter, M. (2014, April). When Friday's workload feels like Monday's: How unfinished tasks enhance employees' rumination over the weekend. Paper presented at the 11th conference of the European Academy of Occupational Health Psychology, London, England.

Theorell, T., and Hasselhorn, H. M. (2005). On cross-sectional questionnaire studies of relationships between psychosocial conditions at work and health-Are they reliable? International Archives of Occupational and Environmental Health, 78(7): 517-522. doi: http://dx.doi.org/10.1007/s00420-005-0618-6.

Thilander, P. (2013). Personalarbete och HR-transformation - Om samspel och relationer mellan linjechefer och HR-medarbetare [Personal work and HR transformation: Interaction and relationships between line managers and HR staff] (Doctoral dissertation, University of Gothenburg, Sweden).

Törnsén, M. (2010). Keys to successful leadership: High support for capable and versatile principals. The Educational Forum, 74(2): 90-103.

Trydegård, G.-B. (2000). Tradition, change and variation: Past and present trends in public old-age care (Doctoral dissertation, University of Stockholm, Sweden). Retrieved from: www.diva-portal.org/smash/get/diva2:197356/FULLTEXT01.pdf.

Van den Broeck, A., De Cuyper, N., Luyckx, K., and de Witte, H. (2012). Employees' job demands-resources profiles, burnout and work engagement. Economic and Industrial Democracy, 33(4): 691-706. doi: http://dx.doi.org/10.1177/0143831X11428228.

Van den Broeck, A., Van Ruysseveldt, J., Vanbelle, E., and de Witte, H. (2013). The job demands-resourcesmodel:Overview and suggestionsforfuture research.AdvancesinPositive Organizational Psychology, 1, 83-105.doi: http://dx.doi.org/10.1108/S2046-410X(2013) 0000001007.

Waldenström, K. (2007). Externally assessed psychosocial work characteristics: A methodological approach to explore how work characteristics are created, related to self-reports and to mental illness. (Doctoral dissertation, Karolinska Institutet, Sweden). Retrieved from: diss.kib.ki.se/2007/978-91-7357-250.../thesis.pdf.

Waldenström, K., Ahlberg, G., Bergman, P., Forsell, Y., Stoetzer, U., Waldenström, M., and Lundberg, I. (2008). Externally assessed psychosocial work characteristics and diagnoses of anxiety and depression. Occupational and Environmental Medicine, 65, 90-97. doi: http://dx.doi.org/10.1136/oem.2006.031252.

Waldenström, K., and Härenstam, A. (2008a). Does the job demand-control model correspond to externally assessed demands and control for both women and men? Scandinavian Journal of Public Health, 36: 242-249. doi: http://dx.doi.org/10.1177/1403494807085079.

Waldenström, K., and Härenstam, A. (2008b). How are good and bad jobs created? Case studies of employee, managerial and organizational factors and processes. Work Life in Transition, 4: 1-52. 
Waldenström, M., Josephson, M., Persson, C., et al. (1998). Interview reliability for assessing mental work demands. Journal of Occupational Health Psychology, 3: 209-216. doi: http://dx.doi.org/10.1037/1076-8998.3.3.209.

Waldenström, K., Lundberg, I., Waldenström, M., et al. (2003). Does psychological distress influence reporting of demands and control at work? Occupational and Environmental Medicine, 60: 887-891. doi: http://dx.doi.org/10.1136/oem.60.11.887.

Waldenström, M., Theorell, T., Ahlberg, G., et al. (2002). Assessment of psychological and social current working conditions in epidemiological studies: Experiences from the MUSIC-Norrtälje study. Scandinavian Journal of Public Health, 30: 94-102. doi: http://dx. doi.org/10.1177/14034948020300020301.

Wolmesjö, M. (2008). Ledarskapets autonomi - om chefers dilemman och handlingsutrymme. [Leadership autonomy - on managers' dilemmas and room for action]. In K. Jonnergård (Ed.), När den professionella autonomin blir ett problem (pp. 141-161). Växjö, Sweden: Växjö University Press. Retrieved from: http://lnu.diva-portal.org/smash/get/diva2: 206458/FULLTEXT01.pdf.

Xanthopoulou, D., Bakker, A. B., Dollard, M. F., Demerouti, E., Schaufeli, W. B. Taris, T.W., and Schreurs, P. (2007). When do job demands particularly predict burnout? The moderating role of job resources. Journal of Managerial Psychology, 22(8): 766-786. doi: http:// dx.doi.org/10.1108/02683940710837714.

Zapf, D. (2002). Emotion work and psychological well-being: A review of the literature and some conceptual considerations. Human Resource Management Review, 12: 237-268. doi: http://dx.doi.org/10.1016/S1053-4822(02)00048-7. 